\title{
Differential effect of adenosine on rhabdomyosarcoma migration and proliferation
}

\author{
Maciej Tarnowski, Marta Tkacz, Katarzyna Piotrowska, Katarzyna Zgutka, Andrzej Pawlik
}

Department of Physiology, Pomeranian Medical University, Szczecin, Poland

Submitted: 22 May 2017

Accepted: 3 September 2017

Arch Med Sci 2020; 16 (2): 414-427

DOI: https://doi.org/10.5114/aoms.2018.75506

Copyright @ 2018 Termedia \& Banach

\section{Abstract}

Introduction: Adenosine and its receptors are involved deeply in the regulation of tumour biology. Purine nucleotides are released from stressed cells in states of hypoxia or radiochemotherapy-induced cell damage. Adenosine exerts its effect through the P1 family of selective receptors. The purpose of the study was to evaluate the exact role of extracellular role on biology of Rhabdomyosarcoma (RMS) cells.

Material and methods: Series of in vitro studies accompanied by immunohistochemical, RQ-PCR and shRNA methods have characterised adenosine receptor expression on Rhabdomyosarcoma cell lines, normal skeletal muscle and effect of adenosine on Rhabdomyosarcoma growth and migration.

Results: Extracellular adenosine (highest at $50 \mu \mathrm{M}, p<0.05$ ) and AMP (highest at $300 \mu \mathrm{M}, p<0.05)$ markedly enhanced chemotaxis in the Boyden chamber assay The reaction is mostly governed by the A1 receptor, which is greatly overexpressed in Rhabdomyosarcoma as compared with normal skeletal muscle. Cell migration induced by adenosine and AMP is blocked by pertussis toxin, phospholipase $C$ and MAP kinase inhibitor, which demonstrates the importance of these signalling pathways. High doses of adenosine have a detrimental effect on cellular proliferation, in a receptor-independent manner $(\geq 500 \mu \mathrm{M} ; p<0.05)$. The blockage of adenosine transporter by dipyridamole abolishes this effect, indicating involvement of an intrinsic pathway. Further increase of adenosine concentration, induced by deaminase inhibitors, augment the effect.

Conclusions: Our results suggest that adenosine and AMP trigger cell migration by binding to $\mathrm{P} 1$ receptors and directing cancer cells to the sites of hypoxia or cellular damage. Specifically by A1 receptor which is overexpressed in RMS.

Key words: cancer, proliferation, apoptosis, cell migration.

\section{Introduction}

Adenosine (Ado) is omnipresent and released from almost all cells. It has been shown to affect a variety of cellular functions including cardiovascular, central nervous system, blood coagulation, angiogenesis and the immunological system. Tissue ischemia, cellular apoptosis, tissue damage and inflammation lead to increased release of purine nucleotides, whose concentrations may rise 100-fold [1-3]. Adenosine is mostly generated in the extracellular space by breakdown of ATP through a series of ectoenzymes, including apyrase (CD39) and 5'-nucleotidase (CD73) or by degradation of nucleic acids via the uric acid pathway during cellular injury [4].

\author{
Corresponding author: \\ Maciej Tarnowski PhD \\ Department of Physiology \\ Pomeranian Medical \\ University \\ Al. Powstancow \\ Wielkopolskich 72 \\ 70-111 Szczecin, Poland \\ Phone: +48914661611 \\ E-mail: maciejt@pum.edu.pl
}


Four receptor subtypes - A1, A2A, A2B and A3 - specifically bind and are activated by elevated levels of adenosine. The adenosine receptors (ARs) are seven transmembrane glycoproteins coupled with different types of $G$ proteins. They differ in their affinity for adenosine, and in the downstream signalling pathways that are activated in the target cells. $\mathrm{A} 1$ and $\mathrm{A} 3$ receptors are coupled to $\mathrm{Gi} / \mathrm{o}$ proteins and their stimulation decreases intracellular cyclic AMP (CAMP) levels, while Gs-coupled A2A and A2B receptors increase $C A M P$ levels through the activation of adenylyl cyclase [5]. Furthermore, depending on the cell type studied, ARs may also signal through activation of the mitogen-activated protein kinase (MAPK) signalling pathway. The MAPK pathways are critically important in the regulation of cell proliferation, migration and differentiation [6-8]. In cancer, adenosine receptors have been shown to be overexpressed in malignant tissues and play important roles in regulating cancer proliferation, apoptosis and chemotaxis [9, 10]. Importantly, adenosine, whose concentration increases within hypoxic regions of solid tumours, has been recognized to interfere with the recognition and destruction of tumour cells by cytolytic effector cells of the immune system [3]. It profoundly inhibits the function of phagocytes and T lymphocytes $[3,11,12]$.

Rhabdomyosarcoma (RMS) is a tumour that derives from early skeletal muscle cells or pluripotent mesenchyme and displays characteristics of muscle cells such as abundant glycogen and myofibrils [13-15]. It is the most common soft-tissue sarcoma of the head and neck in childhood and comprises $4 \%$ of all paediatric malignancies, with $10 \%$ of all cases occurring in the orbit [16]. There are two major histological subtypes of RMS: alveolar (A)RMS and embryonal (E)RMS. Clinically ARMS subtype is more aggressive and has a significantly worse outcome than ERMS. It is well known that RMS cells, particularly ARMS cells, can infiltrate the bone marrow (BM) and, because they can resemble haematological blasts, are sometimes misdiagnosed as acute leukaemia blasts. Current management includes surgery, irradiation and chemotherapy depending on the stage $[17,18]$.

Multiple factors including application of the treatment strategies, hypoxia related to solid tumour environment and even local muscle activity or blood flow may cause adenosine release and elevate its concentration. What is more, purine nucleotides and adenosine may be released and their concentrations highly elevated as a result of radio- or chemotherapy-induced cell damage [19-21]. Based on the above, the present study was undertaken to examine the possible roles of adenosine and adenosine receptor agonists in regulating metastasis and proliferation of rhabdomyosarcoma cancer cells.

\section{Material and methods}

\section{Reagents}

Adenosine, AMP (adenosine 5'-monophosphate disodium salt), DPCPX (8-cyclopentyl-1,3-dipropylxanthine), EHNA hydrochloride, pentostatin (dCF), and dipyridamole (DPM) were obtained from Sigma Aldrich (St Louis, MO). PD 184352 (2-[(2-chloro-4-iodophenyl)amino]-N-cyclopropylmethoxy)-3,4-difluorobenzamide), U 73122 (1-[6-[[(17 $\beta)-3-m e t h o x y e-$ stra-1,3,5(10)-trien-17-yl]amino]hexyl]-1H-pyrrole -2,5-dione), ANR 94 (8-ethoxy-9-ethyl-9H-purin-6amine), PSB 603 (8-[4-[4-(4-Chloro phenzyl)piperazide-1-sulfonyl)phenyl]]-1-propylxanthine), MRS 1220 (N-[9-chloro-2-(2-fura nyl)[1,2,4]-triazolo[1,5-c] quinazolin-5-yl]benzene acetamide), pertussis toxin (50 ng/ml), IB-MECA (1-deoxy-1-[6-[[(3-iodophenyl) methyl]amino]-9H-purin-9-yl]- $N$-methyl- $\beta$-D-ribofuranuronamide), and CPA ( $N$-cyclopentyladenosine) were purchased from Tocris (Ellisville, MO). SDF-1 was from PeproTech (London, UK).

\section{Cell lines}

We used human RMS cell lines RH30 (ARMS) and RD (ERMS) (purchased in ATCC). RMS cells used for experiments were cultured in Roswell Park Memorial Institute medium (RPMI) 1640 and Dulbecco's Modified Eagle's Medium (DMEM) (both Sigma, St. Louis, MO), supplemented with $100 \mathrm{IU} / \mathrm{ml}$ penicillin and $10 \mathrm{\mu g} / \mathrm{ml}$ streptomycin (Life Technologies, Inc., Grand Island, NY) in the presence of $10 \%$ heat-inactivated fetal bovine serum (FBS, Life Technologies). The cells were cultured in a humidified atmosphere at $37^{\circ} \mathrm{C}$ in $5 \%$ $\mathrm{CO}_{2}$ at an initial cell density of $2.5 \times 10^{4}$ cells/flask (Corning, Cambridge, MA) and the media were changed every $48 \mathrm{~h}$.

\section{Immunofluorescent (IF) analysis of paraffin-embedded muscle tissue and RMS}

Three- $\mu \mathrm{m}$-thick muscle tissue sections were deparaffinized twice in xylene (40 $\mathrm{min}$ and $20 \mathrm{~min}$ ), rehydrated in alcohol (100\%, 95\%, 80\%, and $70 \%)$, and transferred to deionized water. After antigen retrieval in a microwave oven for $10 \mathrm{~min}$ in citrate buffer $\mathrm{pH}=6$ (Dako Denmark) and incubation with blocking serum, adenosine A1R, A2AR, $A 2 B R, A 3 R$ antibody were added (rabbit polyclonal anti-A1R/A2AR/A3R antibody or goat polyclonal anti-A2BR antibody, Santa Cruz Biotechnology) at 1 : 100 dilution for $1 \mathrm{~h}$ at room temperature (RT). After incubation with primary antibody and washing twice in PBS, the samples were incubated with secondary antibodies at $1: 200$ dilution for $1 \mathrm{~h}$ at RT (A1R, A2AR, A3 chicken anti-rabbit Alexa Fluor 488, Thermo Fisher Scientific; RMS A2BR rabbit anti-goat Texas Red, Sigma Aldrich; 
muscle A2BR rabbit anti-goat Texas Red, Vector Laboratories). Nuclei were visualized with DAPI (Sigma Aldrich). Section images were acquired under an Observer Z1 microscope (Zeiss, Germany), with an AxioCam MRm camera (Zeiss, Germany) and micrographs were analyzed with the AxioVision Rel.4.8 system (Zeiss, Germany). Cells were seeded in 6-well culture plates on cover glasses at $3 \times 10^{4}$ and cultured as above for $24 \mathrm{~h}$. Next, the cells were fixed in $4 \%$ neutral buffered formalin (5 min). After double washing in PBS cells were permeabilised with $0.1 \%$ TRITON-X100 solution in PBS for 10 min and after washing in PBS incubated with blocking serum solution. Further steps of the staining procedure were the same as in the case of histological slides. All the steps were performed in the dark. The slides were examined with the AxioVision Rel.4.8 system (Zeiss, Germany).

\section{Chemotaxis assay}

The $8-\mu \mathrm{m}$ polycarbonate membranes were covered with $50 \mu \mathrm{l}$ of $0.5 \%$ gelatin. Cells were detached with $0.5 \mathrm{mmol} / \mathrm{l}$ ethylenediaminetetraacetic acid (EDTA), washed in culture medium, resuspended in RPMI 1640 or DMEM with $0.5 \%$ BSA, and seeded at a density of $3 \times 10^{4}$ in $120 \mu \mathrm{l}$ into the upper chambers of Transwell inserts (Costar Transwell; Corning Costar, Corning, NY). The lower chambers were filled with adenosine (0.05-1000 $\mu \mathrm{M})$, AMP $(0.03-3000 \mu \mathrm{M})$, DPCPX (50 nM, $500 \mathrm{nM})$, ANR $94(1 \mu \mathrm{M}, 10 \mu \mathrm{M})$, PSB 603 (500 nM, $1000 \mathrm{nM})$, MRS 1220 (1 nM, $10 \mathrm{nM})$, pertussis toxin $(50 \mathrm{ng} / \mathrm{ml}), P D 184352$ $(5 \mu \mathrm{M}), \mathrm{U} 73122(5 \mu \mathrm{M})$, IB-MECA $(10 \mu \mathrm{M}), \mathrm{CPA}$ $(10 \mathrm{nM})$ or $0.5 \%$ BSA RPMI 1640 or DMEM (negative control) or with SDF-1 (300 $\mathrm{ng} / \mathrm{ml}$ ) (positive control). After $24 \mathrm{~h}$, the inserts were removed from the Transwells. Cells remaining in the upper chambers were scraped off with cotton wool and cells that had transmigrated were stained with HEMA 3 according to the manufacturer's instructions (Fisher Scientific, Pittsburgh, PA) and counted either on the lower side of the membranes or on the bottom of the Transwells.

\section{Cell proliferation}

Cellswere plated in culture flasks at an initialdensity of $10^{3}$ cells $/ \mathrm{cm}^{2}$ in the presence or absence of adenosine (0.05-1000 $\mu \mathrm{M})$, AMP $(0.03-3000 \mu \mathrm{M})$, DPCPX (50 nM), ANR $94(1 \mu M)$, PSB 603 (500 nM), MRS $1220(1 \mathrm{nM})$, DPM $(5 \mu \mathrm{M})$, EHNA $(10 \mu \mathrm{M})$ or dCF $(50 \mu \mathrm{M})$. The cell number was calculated at $72 \mathrm{~h}$ after culture initiation. At the indicated time points, cells were harvested from the culture plates by trypsinization and the number of cells was determined using a Navios cytometer (Beckman Coulter).

\section{Phosphorylation of intracellular pathway proteins and Western blotting}

Western blots were performed on extracts prepared from RMS cell lines $\left(3 \times 10^{6}\right.$ cells) that were kept in RPMI or DMEM medium containing low levels of bovine serum albumin (BSA, $0.5 \%$ ) to render the cells quiescent. The protocol used herein is standard in our laboratory and was applied as previously described [22]. Briefly, the cells were divided and stimulated with optimal doses of Ado $(50 \mu \mathrm{M})$, and AMP $(300 \mu \mathrm{M})$ for $5 \mathrm{~min}$ at $37^{\circ} \mathrm{C}$ and then lysed (for $10 \mathrm{~min}$ ) on ice in RIPA lysing buffer (Santa Cruz Biotech), containing protease and phosphatase inhibitors (Roche). Subsequently, the extracted proteins were separated by $12 \%$ sodium dodecyl sulfate-polyacrylamide gel electrophoresis (SDS-PAGE) and the fractionated proteins were transferred to a nitrocellulose membrane (Bio-Rad). Phosphorylation of the intracellular kinases, p44/42 mitogen-activated protein kinase (MAPK) (Thr 202/ Tyr 204), was detected using commercial mouse phospho-specific monoclonal antibodies (mAbs) (p42/44) (Cell Signaling) with horseradish peroxidase (HRP)-conjugated goat anti-mouse IgG as a secondary antibody (Santa Cruz Biotech). Equal loading in the lanes was evaluated by stripping the blots and reprobing with appropriate mAbs: p44/42 anti-MAPK clone no. 9102 (Santa Cruz Biotech). A1 receptor expression was visualized with Adenosine A1-R (H-40) Antibody (Santa Cruz Biotech) and GAPDH as a loading control (Abcam). The membranes were developed with an enhanced chemiluminescence $(E C L)$ reagent (GE Healthcare), dried, and visualized by a Chemidoc transilluminator (Bio-Rad).

\section{Annexin V/PI assays for apoptosis}

For annexin V/PI assays, cells were stained with Annexin V-FITC and PI, and evaluated for apoptosis by flow cytometry according to the manufacturer's protocol (BD Pharmingen, San Diego, CA, USA). Briefly, $1 \times 10^{6}$ cells were washed twice with phosphate-buffered saline (PBS), and stained with $5 \mu \mathrm{l}$ of Annexin V-FITC and $10 \mu \mathrm{l}$ of PI $(5 \mu \mathrm{g} / \mathrm{ml})$ in $1 \times$ binding buffer (10 mM HEPES, pH 7.4, $140 \mathrm{mM} \mathrm{NaOH}$, $2.5 \mathrm{mM} \mathrm{CaCl}_{2}$ ) for $15 \mathrm{~min}$ at room temperature in the dark. The apoptotic cells were determined using a Navios flow cytometer (Beckman Coulter). Annexin $\mathrm{V}^{+} \mathrm{Pl}^{-}$cells represented the early apoptotic populations. Annexin $\mathrm{V}^{+} \mathrm{PI}^{+}$cells represented either late apoptotic or secondary necrotic populations.

\section{Real-time quantitative reverse transcription PCR (RQ-PCR)}

Total RNA was isolated from cells treated with Ado and from control cells with the RNeasy Kit (Qiagen). The RNA was reverse-transcribed with MultiScribe reverse transcriptase and oligo-dT 
primers (Applied Biosystems, Foster City, CA). Quantitative assessment of mRNA levels was performed by real-time RT-PCR (RQ-PCR) on an ABI 7500 instrument with Power SYBR Green PCR Master Mix reagent. Real-time conditions were as follows: $95^{\circ} \mathrm{C}(15 \mathrm{~s}), 40$ cycles at $95^{\circ} \mathrm{C}(15 \mathrm{~s})$, and $60^{\circ} \mathrm{C}$ (1 min). According to melting point analysis, only one PCR product was amplified under these conditions. The relative quantity of a target, normalized to the endogenous control $\beta_{2}$ microglobulin gene and relative to a calibrator, is expressed as $2^{-\Delta \Delta C t}$ (fold difference), where $C t$ is the threshold cycle, $\Delta C t=$ (Ct of target genes) $-(C t$ of endogenous control gene, $\beta_{2}$ microglobulin), and $\Delta \Delta C t=$ ( $\Delta C t$ of samples for target gene) - ( $\Delta C t$ of calibrator for the target gene). The following primer pairs were used: CT-3',

$\beta_{2}$ microglobulin F: 5'-AATGCGGCATCTTCAAAC-

$\beta_{2}$ microglobulin R:5'-TGACTTTGTCACAGCCCAAGATA-3',

A1R F: 5'-TGCGAGTTCGAGAAGGTCATC-3', A1R R: 5'-GAGCTGCTTGCGGATTAGGTA-3', A2AR F: 5'-CGAGGGCTAAGGGCATCATTG-3', A2AR R: 5'-CTCCTTTGGCTGACCGCAGTT-3', A2BR F: 5'-CTCTTCCTCGCCTGCTTCGTG-3', A2BR R: 5'-TTATACCTGAGCGGGACACAG-3',

\section{A3R F: 5'-TACATCATTCGGAACAAACTC-3',} A3R R: 5'-GTCTTGAACTCCCGTCCATAA-3'.

Knockdown of $A 1 R$ with short hairpin RNA. In RNAi experiments, the short hairpin RNA (shRNA)generating plasmid pLKO1 (Sigma Aldrich) was used. The oligonucleotide-targeting base sequence for human A1R was: 5'-CAAGATCCCTCTCCGGTACAA-3'. RMS cells were plated at $80 \%$ confluency and transfected with a shRNA vector using Lipofectamine (Invitrogen) according to the manufacturer's protocol. A commercially available scrambled shRNA negative control plasmid was used (Sigma Aldrich). For stable transfection of shRNA-producing vectors, single-cell dilutions were prepared and the cells further expanded in the presence of puromycin $(1 \mu \mathrm{g} / \mathrm{ml}$, Invitrogen)

\section{Statistical analysis}

All results are presented as mean \pm standard error of the mean (SEM). Statistical analysis of the data was performed using the nonparametric Student's $t$-test, with $p<0.05$ considered significant.

\section{Results}

Firstly, in attempt to characterize the function of adenosine receptors we evaluated $A 1 R, A 2 A R$,
A
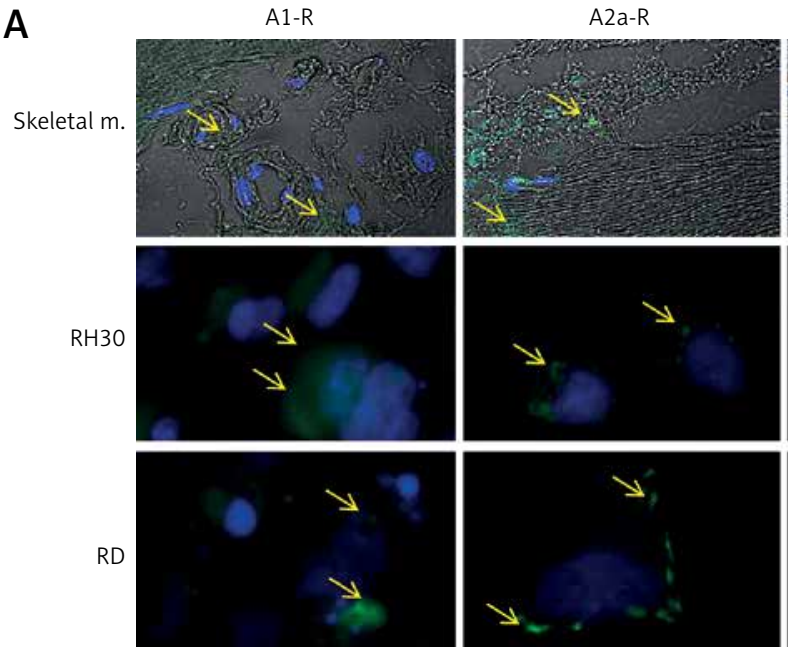
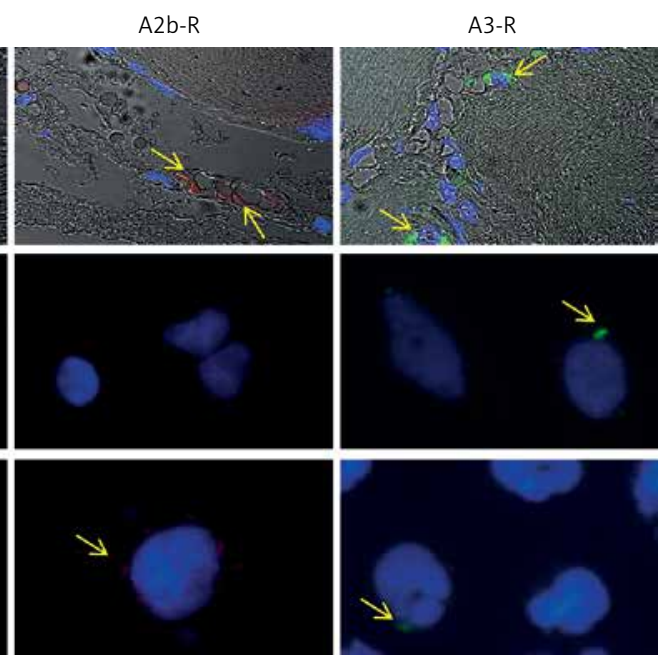

B

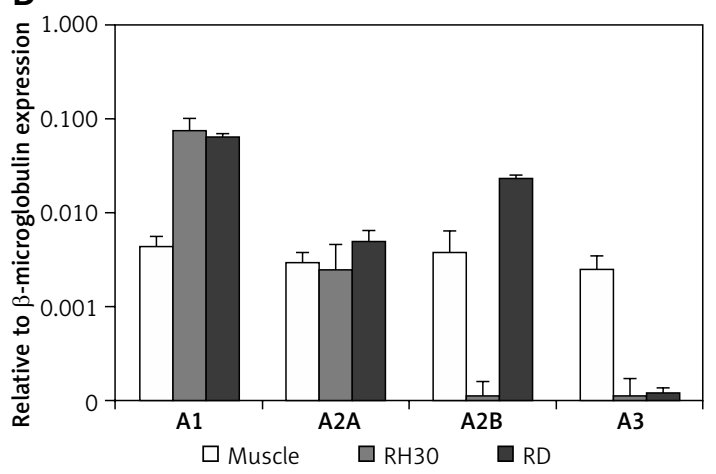

Figure 1. Immunofluorescent expression of adenosine receptors (ARs) in skeletal muscle tissue and cell lines (A). Skeletal muscle tissue fragments - A1R A2AR and A3R secondary antibodies Alexa Fluor 488, A2BR combined with Texas Red; objective magnification 60x, zoom 1.9; images fitted to a panel in size; merged with transmission light channel for more detailed tissue visualization (FV100 Confocal system). RH30 and RD cell lines A1R A2AR and A3R secondary antibodies Alexa Fluor 488, A2BR combined with Texas Red objective magnification 40x - images cut off from original size microphotographs (Axiobserver). Yellow arrows indicate positive reaction in $\mathrm{RH} 30$ and $\mathrm{RD}$ cells. RQPCR analysis of ARs mRNA levels in muscle tissue and RMS cell lines (B) 
Table I. Immunoexpression of adenosine receptors in cell lines and tissue samples

\begin{tabular}{|lcccc|}
\hline Variable & A1-R & A2a-R & A2b-R & A3-R \\
\hline Skeletal muscle & + & + & ++ & ++ \\
\hline RH30 cell line & +++ & ++ & + & + \\
\hline RD cell line & +++ & ++ & ++ & + \\
\hline
\end{tabular}

+++ Very strong expression, ++ strong expression, + weak expression, +/-very weak expression, - no expression.

$A 2 B R$ and $A 3 R$ expression in normal skeletal muscle and the RMS cell lines RH30 and RD (Figure 1, Table I) that belong to ARMS and ERMS rhabdomyosarcoma subtypes, respectively. Additionally, we included smooth muscle tissue as a positive control. Both immunohistochemical staining and RQ-PCR analysis revealed increased expression of
$\mathrm{A} 1$ and $\mathrm{A} 2 \mathrm{~B}$ receptors in RMS cell lines when compared to normal muscle tissue. The $A 2 B$ receptor is present only in the RD cell line and skeletal muscle tissue, whereas it is absent on RH30 cells. The A3 receptor is relatively weakly expressed in RMS cells.

Adenosine receptors possess high (A1 and $A 3$ ) and low (A2A and A2B) affinity to adenosine [23]. Thus, they may be stimulated by lower and higher doses of Ado. Recently it was shown that extracellular AMP is a putative ligand of the A1 receptor [24]. In further experiments, we used both Ado and AMP for adenosine receptor stimulation.

It was previously shown that adenosine receptors are involved in cell migration, and thus may play an important role in cancer cell metastasis. To better address this phenomenon we employed modified Boyden chambers in order to evaluate
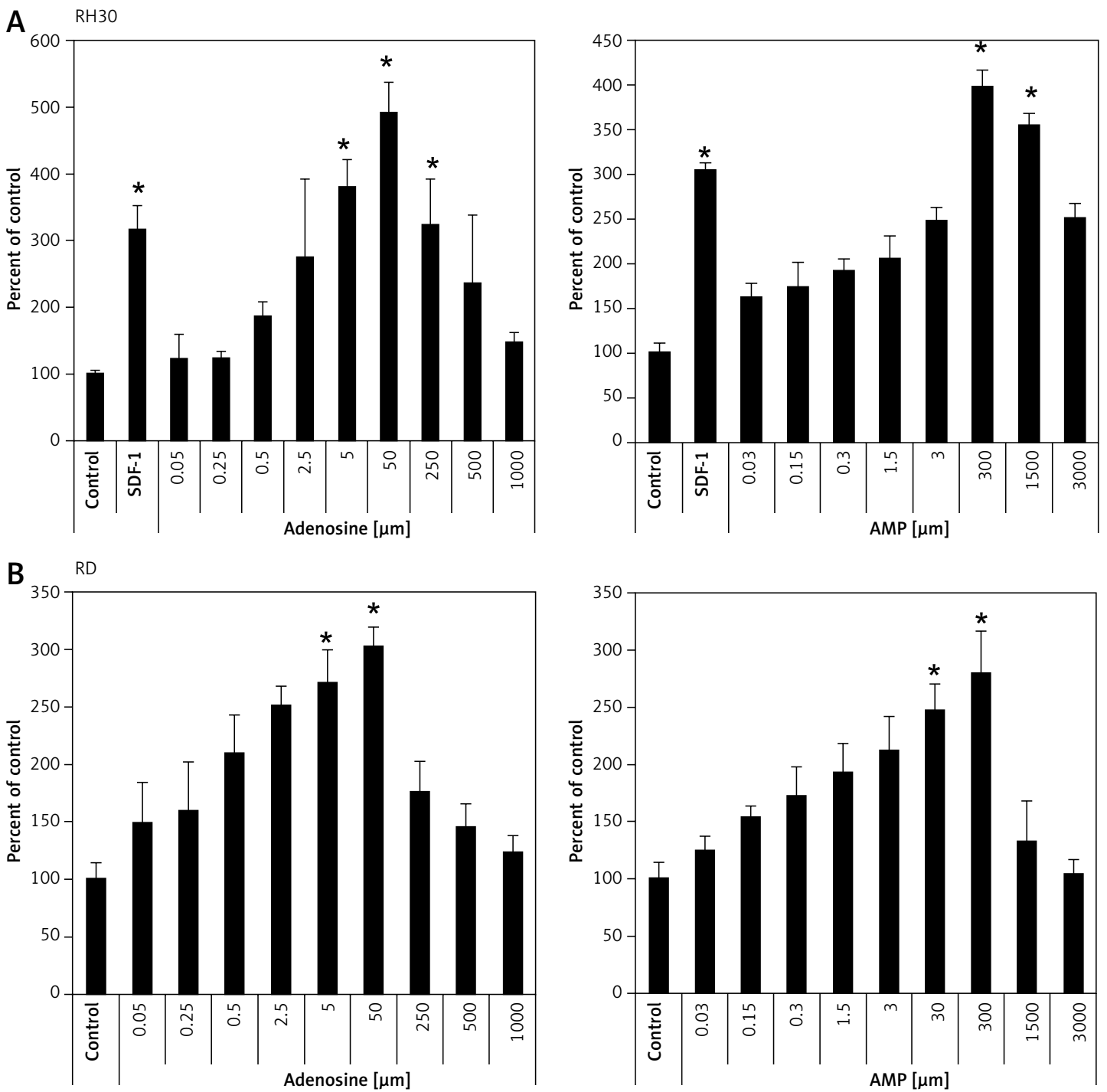

Figure 2. RH30 cell line migration induced by different concentrations of adenosine (A) and AMP (B) was detected by transwell migration assay. SDF-1 $(300 \mathrm{ng} / \mathrm{ml})$ served as a positive control. Data are shown as mean \pm SEM. All experiments were repeated three times with similar results ${ }^{\star} P<0.05$. 
the chemotactic potential of extracellular adenosine and AMP. First, a dose response experiment allowed us to visualize cell migration upon stimulation by a range of doses of adenosine $(0.05-1000$ $\mu M)$ and AMP (0.03-3000 $\mu M)$. We found that increasing doses of both molecules strongly affected chemotaxis, reaching an optimum at $50 \mu \mathrm{M}$ for adenosine and $300 \mu \mathrm{M}$ for AMP (Figure 2). In all further chemotactic studies the optimal concentrations were used. In the next set of experiments, we employed specific antagonists of adenosine receptors, namely DCPX for A1R, ANR 94 for A2AR, PSB 603 for A2BR and MRS 1220 for A3R (Figure 3). Both RH30 and RD cells significantly decreased their mobility towards adenosine and AMP when increasing doses of DPCPX were applied, which makes A1R the key receptor involved in the chemotactic response to the gradient of Ado and AMP. We noted that chemotactic potential was also affected by blocking of the $\mathrm{A} 3$ receptor, but its expression is not high, so its effect on cell migration is small (Figures 1, 3). To further support this notion, we employed the shRNA technique in order to decrease $\mathrm{A} 1$ expression. The genetically modified RH30 cell line exhibited decreased A1 receptor expression (by $85 \%$ ) and reduced chemotactic responsiveness to both adenosine and AMP gradients (Figure 4). Blockage of $A 2 A$ and $A 2 B$ receptors did not cause a significant decrease in cell migration, except for the $\mathrm{A} 2 \mathrm{~B}$ receptor in RD cells stimulated with Ado (Figure 3 ). The above experiments show that extracellular Ado and AMP are potent chemoattractants for RMS cells. The A1 receptor is a key element involved in the response. Of note, a chemotactic response may be evoked by a gradient of specific $A 1$ and $A 3$ agonists, CPA and IB-MECA, respectively (data not shown).

In order to better characterize responses triggered by adenosine and AMP, we evaluated signal transduction pathway activation by western blot visualization of MAPK p44/42 (Erk1/2) kinase phosphorylation at Thr202/Tyr204 and Thr185/ Tyr187, respectively (Figure 5 A). Moreover, application of the MAPK inhibitor PD184352, as well as pertussis toxin or the phospholipase $C$ inhibitor U73122, significantly blocked the chemotactic response of RH30 and RD cells (Figures 5 B, C).

Based on our results presented in Figure 2, we noted that application of upper-range doses of Ado and AMP (above $50 \mu \mathrm{M}$ and $300 \mu \mathrm{M}$ ) led to a significant decrease in their chemotactic responsiveness. Therefore, we performed a proliferation test in order to evaluate the effect of Ado and AMP on cell survival in a time- and dose-dependant manner.

Figure 6 shows that treating cells with chemotactically optimal (50 $\mu \mathrm{M}$ and $300 \mu \mathrm{M})$ or higher doses of Ado and AMP, respectively, for $72 \mathrm{~h}$ led to decreased proliferation of both $\mathrm{RH} 30$ and RD cells. Specifically, it is the adenosine that has a significant anti-proliferative effect. RD cells are more sensitive to high doses of Ado and AMP. As shown in Figure 7, by employing PI staining and annexin- $\mathrm{V}$ binding we observed that increasing doses of Ado trigger an apoptotic reaction in $\mathrm{RH} 30$ cells. We may speculate that Ado accumulates in a time-dependent manner and negatively influences cell proliferation and cell survival. Since Ado is known to exert its effect through an extrinsic pathway (receptor-based) or intrinsic pathway (transporter based) [25] we applied receptor antagonists as well as deaminases and Ado transporter inhibitors.

Therefore, in order to clarify this issue, we stimulated RMS cells with increasing doses of Ado $(50 \mu \mathrm{M}$ and $500 \mu \mathrm{M})$ for $72 \mathrm{~h}$ and systematically blocked 4 receptors with previously mentioned antagonists. The receptor antagonists did not prohibit cytotoxic Ado activity, and this was not mediated by adenosine receptors (Figure 8). Next, we employed specific inhibitors of nucleoside membrane transporter (dipyridamole - DPM), adenosine deaminase erythro-9-(2-hydroxy-3-nonyl)adenine (EHNA) and 2'-deoxycoformycin (dCf). Figure 8 shows that blockage of the adenosine transporter by DPM significantly increased survival of RMS cells stimulated by Ado, whereas when adenosine deaminase inhibitors were applied the survival was affected much more than by adenosine itself. We noted the same situation for both cell lines, with RD cells being more prone to cytotoxicity induced by adenosine.

\section{Discussion}

Adenosine is a very important molecule that exists in both intracellular and extracellular environments, at a wide range of concentrations. Adenosine may be released directly by multiple cell types, with extracellular concentrations in the nanomolar range. Adenosine release and generation greatly rise in situations of physiological stress such as trauma, hypoxia or inflammation and can reach the micromolar range. Tissue levels can significantly rise [26]. Intracellular adenosine is exported from cells via equilibrative nucleoside transporters or during apoptosis or necrosis. What is important, accumulation of extracellular nucleotides and products of its degradation is augmented as a result of chemo- and radiotherapy - strategies which are commonly used in cancer treatment $[19,21]$. Apart from direct Ado release, a significant amount is produced as a result of ATP degradation. ATP in the extracellular environment is quickly dephosphorylated by a complex of cell surface-located enzymes named ectonucleotidases including ecto-NTPDases (nucleoside tri- 
A
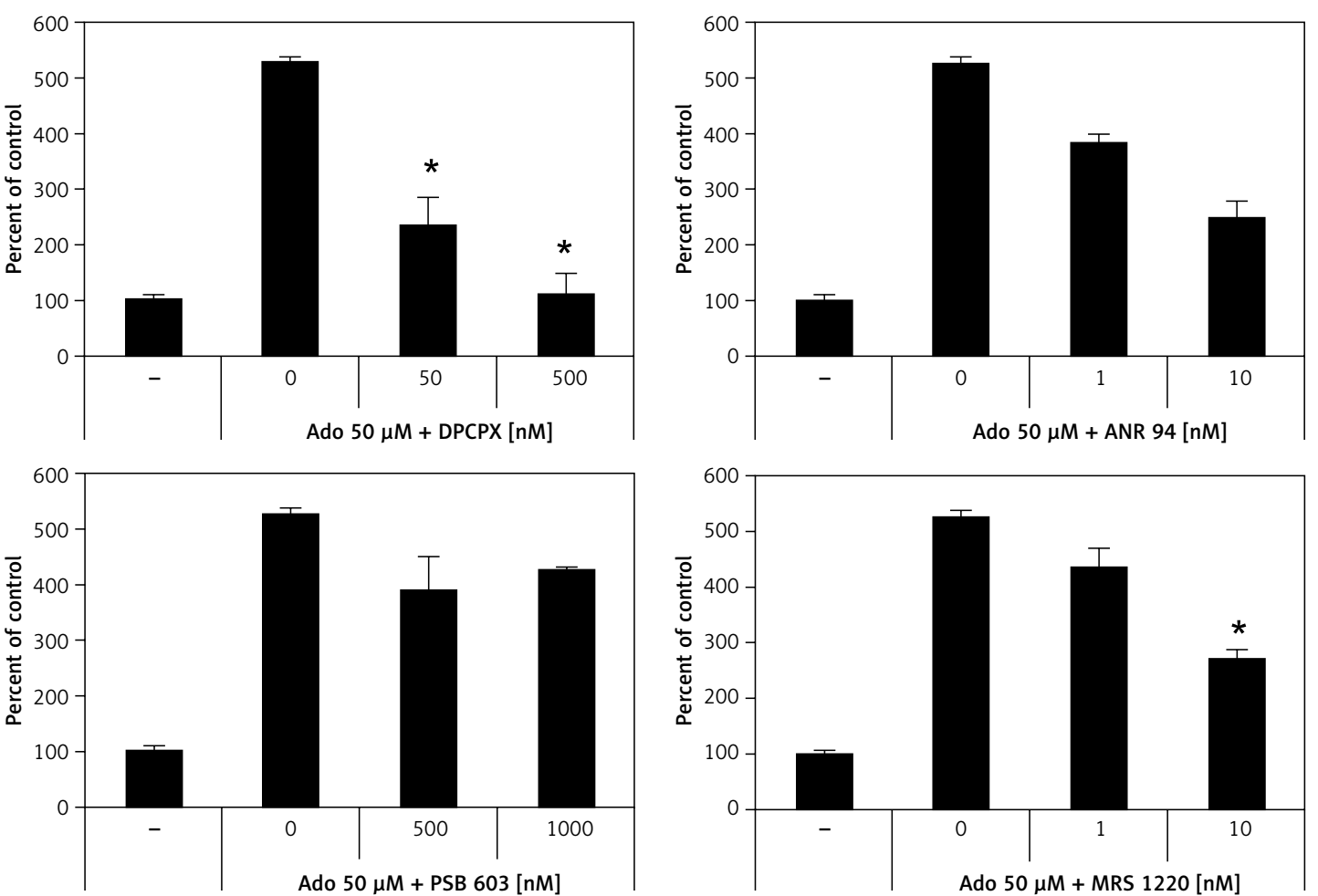

B
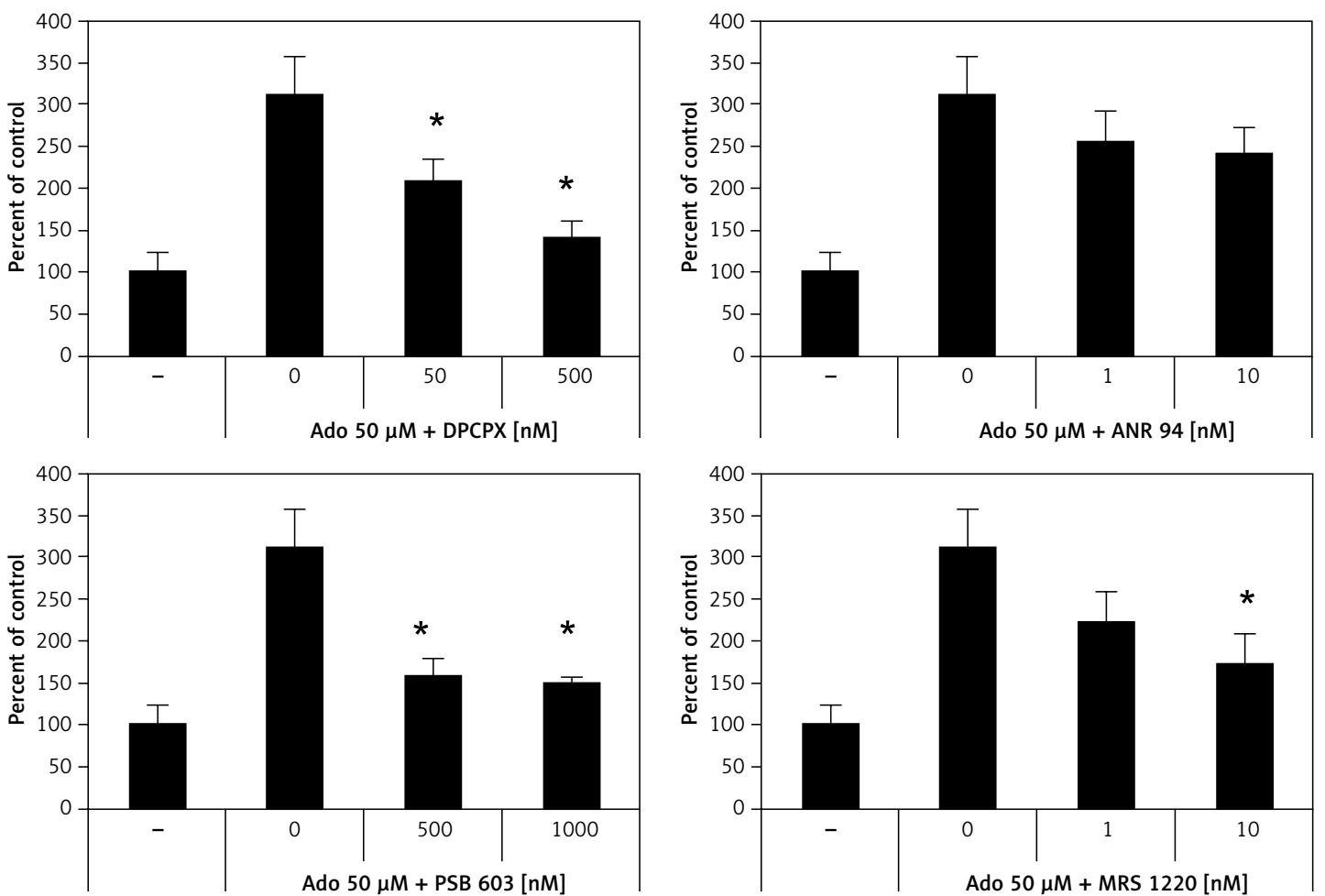

Figure 3. Blockage of migration induced by adenosine $(50 \mu \mathrm{M})(\mathrm{A}, \mathrm{B})$ and $\mathrm{AMP}(300 \mu \mathrm{M})(\mathrm{C}, \mathrm{D})$ by selected inhibitors: DPCPX (8-cyclopentyl-1,3-dipropylxanthine) for A1R, ANR 94 (8-ethoxy-9-ethyl-9H-purin-6-amine) for A2A, PSB 603 (8-[4-[4-(4-chloro phenzyl)piperazide-1-sulfonyl)phenyl]]-1-propylxanthine) for A2B and MRS 1220 (N-[9chloro-2-(2-furanyl)[1,2,4]-triazolo[1,5-c]quinazolin-5-yl]benzene acetamide) for $A 3 R$. RH30 (A, C) and RD (B, D)

${ }^{*} P<0.05$ versus adenosine. 
C
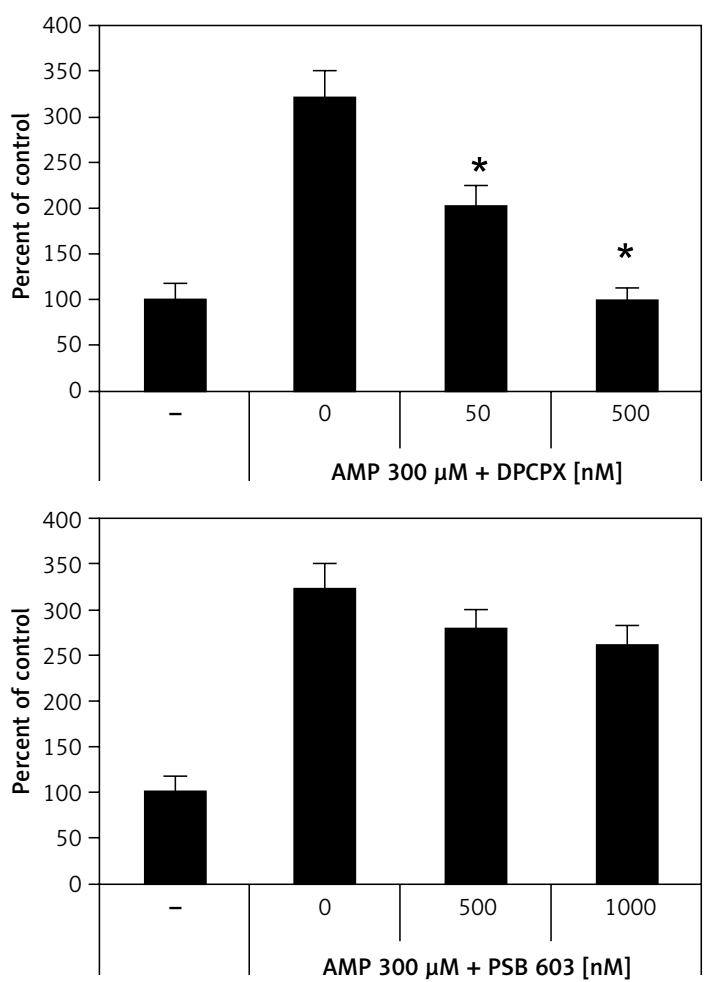

D
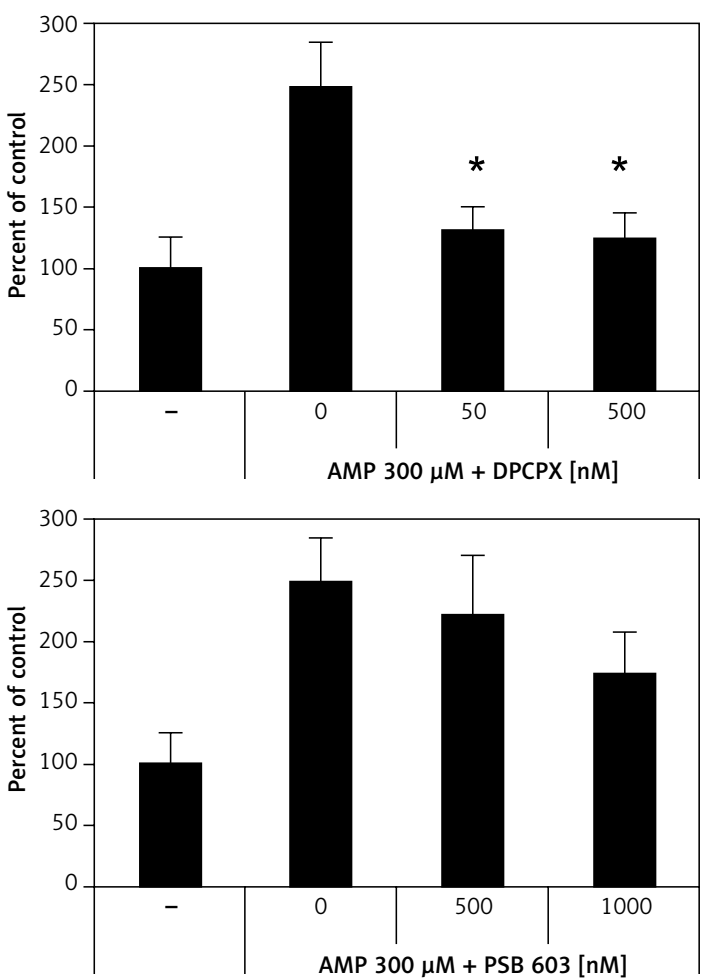

Figure 3. Cont.

${ }^{\star} P<0.05$ versus adenosine.
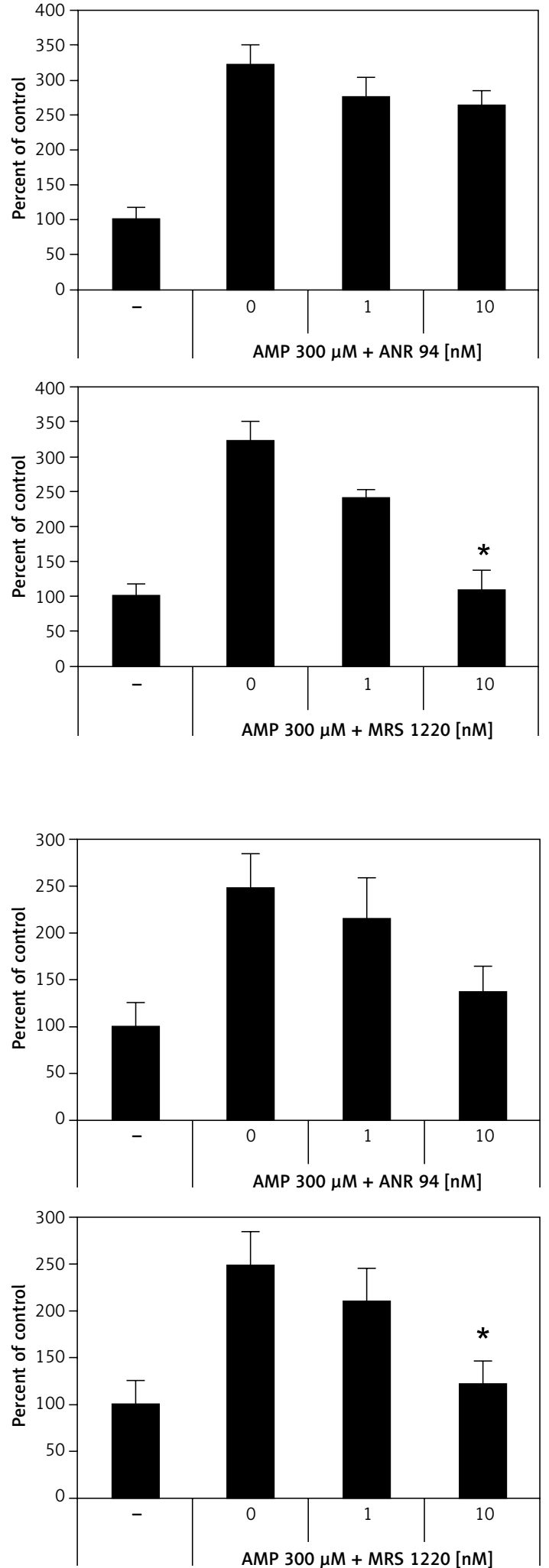
A

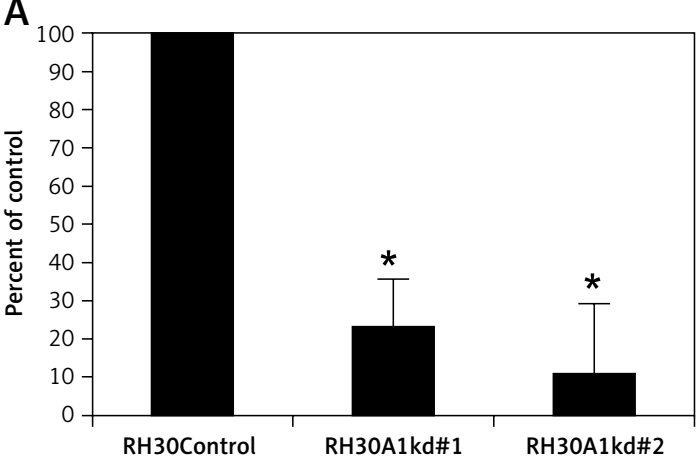

C

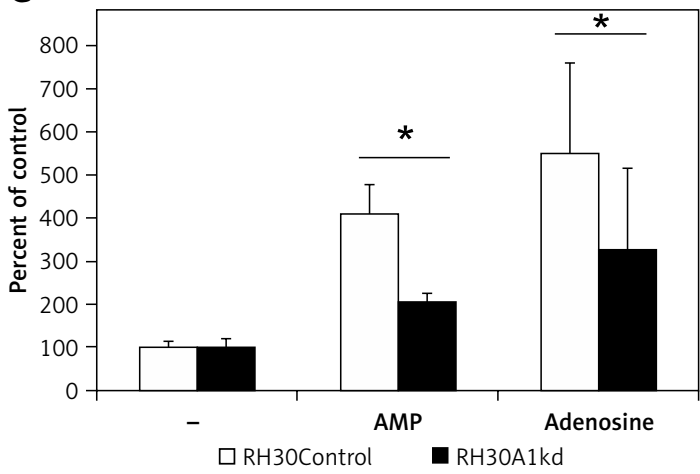

phosphate diphosphohydrolases) such as CD39, ecto-NPPs (nucleotide pyrophosphohydrolases/ phosphodiesterases), ecto-alkaline phosphatases, and ecto-5'nucleotidase (CD73) [27-29]. Therefore, ATP relatively briefly exerts its effects and the concentration of end products of ATP degradation such as adenosine quickly rises.

Adenosine is a ligand for P1 receptors. The family consists of four receptors with different affinity towards adenosine, and therefore they act in a varying spectrum of Ado concentration. All of these ARs are cell surface G protein-coupled receptors which have distinct tissue-specific distributions [5]. In our study we show, for the first time, that rhabdomyosarcoma expresses P1 receptor subtypes and among them the A1 receptor is greatly overexpressed when compared to normal skeletal muscle. Previous immunohistochemical and pharmacological studies have revealed the existence of $A 1, A 2 A$ and $A 2 B$ receptor types in skeletal muscle cells [30, 31]. However, expression of the $\mathrm{A} 1$ receptor is disputable, as it is mostly expressed in endothelial cells and results from mRNA studies on muscle homogenates may falsely overestimate its amount [30]. In our experiment for mRNA studies, we also used muscle homogenates and detected the A1R mRNA transcript in skeletal muscle (Figure 1 B). An immunohistochemical study showed the barely detectable A1 receptor in normal skeletal muscle (Figure $1 \mathrm{~A}$ ). Nonetheless, we may conclude that the A1 receptor is overexpressed in RMS cell lines. In general, P1 receptors
B

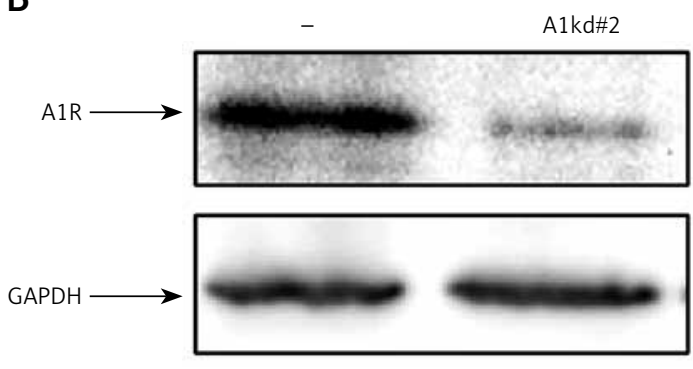

Figure 4. Downregulation of $A 1 R$ expression in RH30 cell line by shRNA. Figure shows decrease in the expression in two selected clones (RH30A1kd) at the mRNA level (A) and protein level (B) visualized by Western blot. $\mathbf{C}$ - The chemotactic response of the RH30A1kd cells to a gradient of adenosine $(50 \mu \mathrm{M})$ and AMP $(300 \mu \mathrm{M})$

${ }^{*} P<0.05$.

are overexpressed in multiple tumours such as breast carcinoma, melanoma or colorectal cancer [32-34] and are extensively involved in cancer biology.

In our study, extracellular adenosine and AMP effectively bound to P1 receptors and activated intracellular signalling transduction pathways involving MAP kinases and phospholipase C, as shown in Figure 5 and by Schulte et al. [35]. Based on our results, the A1 receptor seems to play the most important role in triggering the chemotactic response of RMS cells to the extracellular adenosine and AMP gradient. For both ligands, the chemotactic response was stronger than that to SDF-1, which is a known chemoattractant for RMS cells [22]. Blockage of the receptor by the specific antagonist DPCX or decrease of its expression by shRNA significantly abolished cell migration. Moreover, the experiments indicated that not only adenosine binds to the A1 receptor but also extracellular AMP. Our results are in line with a previously published study by Rittiner et al. [24]. What is more, the chemotactic response was pertussis toxin sensitive, indicating involvement of Gi/o coupled receptors such as A1 or A3 receptors [36]. Migration-stimulating properties of adenosine were previously described; extracellular adenosine stimulates chemotaxis of human endothelial progenitors [37], oligodendrocytes [38] and neutrophils [39] or cancer cells [40]. Moreover, cancer cells such as rhabdomyosarcoma typically overexpressing CD73 (data not shown) 
A
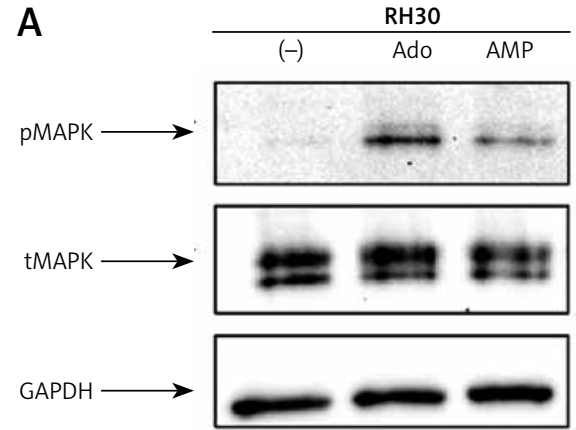
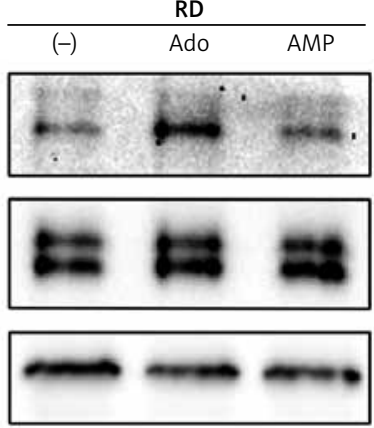

B

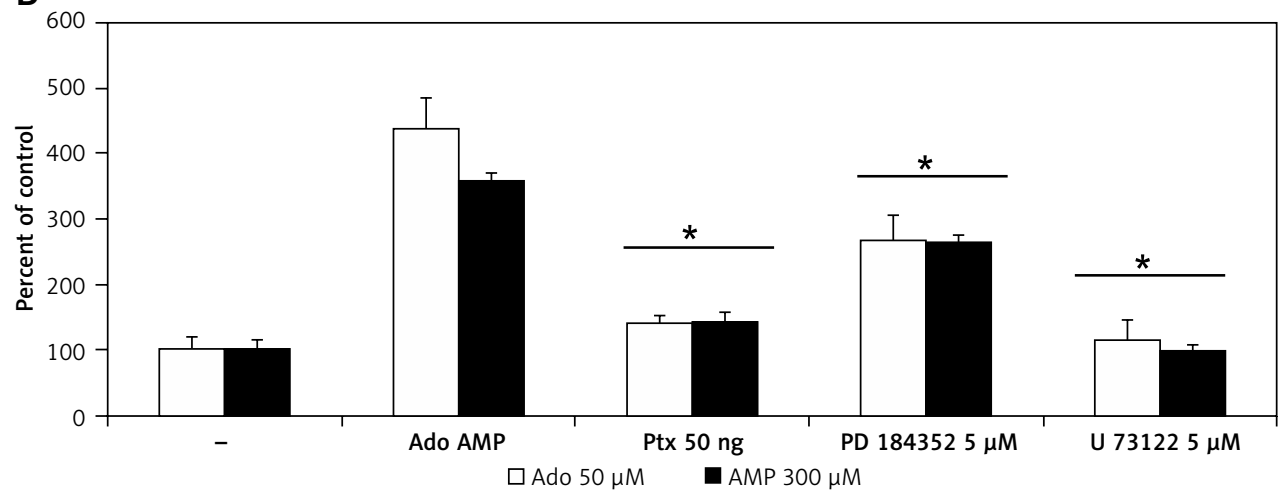

C

$\square$ Ado $50 \mu \mathrm{M}$

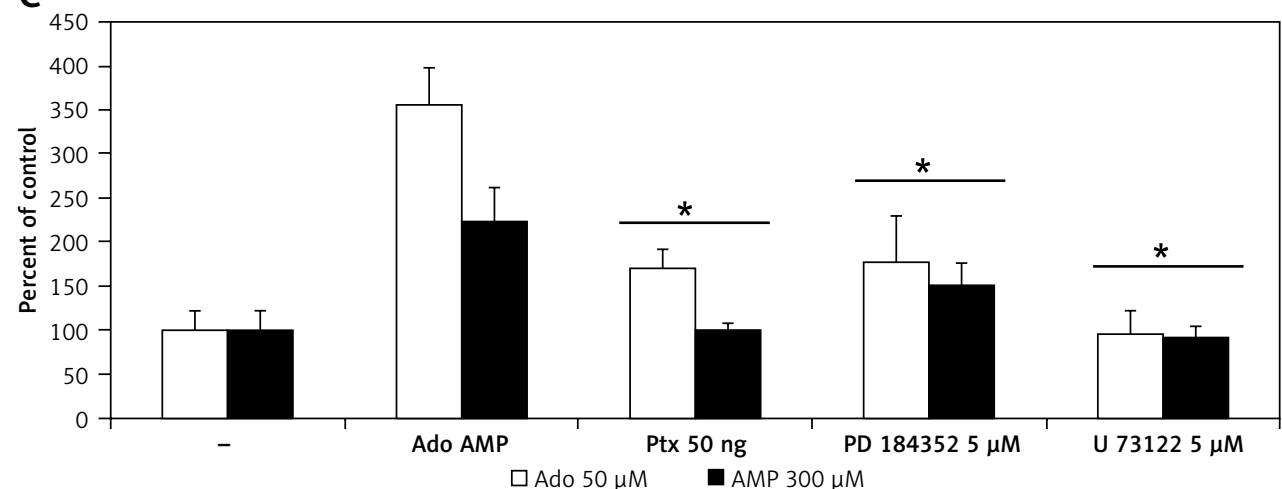

Figure 5. Effect of adenosine and AMP signalling in rhabdomyosarcoma (RMS) cells. RH30 and RD cells were stimulated by adenosine $(50 \mu \mathrm{M})$ or AMP $(300 \mu \mathrm{M})$ for $5 \mathrm{~min}$, and phosphorylation was assessed by Western blotting (A). The experiment was repeated three times with similar results. Inhibition of rhabdomyosarcoma (RMS) cell chemotaxis to adenosine $(50 \mu \mathrm{M})$ and AMP $(300 \mu \mathrm{M})$ by PD184352 $(5 \mu \mathrm{M}), \mathrm{U} 73122(5 \mu \mathrm{M})$ and pertussis toxin (50 ng). Cells were pre-incubated with or without inhibitors for $30 \mathrm{~min}$ at $37^{\circ} \mathrm{C}$. Inhibitors together with adenosine or AMP were placed in the lower wells of the chemotaxis chamber $(B, C)$

${ }^{*} P<0.05$.

and adenosine receptors (Figure 1) may localize the enzymes and receptors in the leading edge of a migrating cell, hence amplifying the gradient of external chemoattractant [41] and thus increasing its own migratory capacity.

Adenosine has been shown to inhibit cell growth and induce apoptosis in several cancer cell lines via intrinsic and extrinsic pathways. The extrinsic pathway is linked to adenosine receptors, while the intrinsic pathway relies on adenosine uptake via adenosine transporters [25]. In our study, we noted that increasing doses of adenosine affect cell proliferation. In many tumour types adenosine is known as a proliferation enhancer
[42-44], while in other cases adenosine receptor agonists served as inducers of apoptosis and tumour growth inhibitors [9, 10, 45]. In our study, RMS cells treated with increasing doses of adenosine showed decreased survival. None of the synthetic adenosine receptor agonists stimulated RMS cell growth (data not shown) and none of the antagonists prevented cell death. We may speculate that with time adenosine accumulates around and inside the cells, exerting a negative effect that leads to cell apoptosis in a receptor-independent manner. It was very interesting to explain how the adenosine affects RMS proliferation. By employing adenosine receptor antagonists, deaminase and 
A

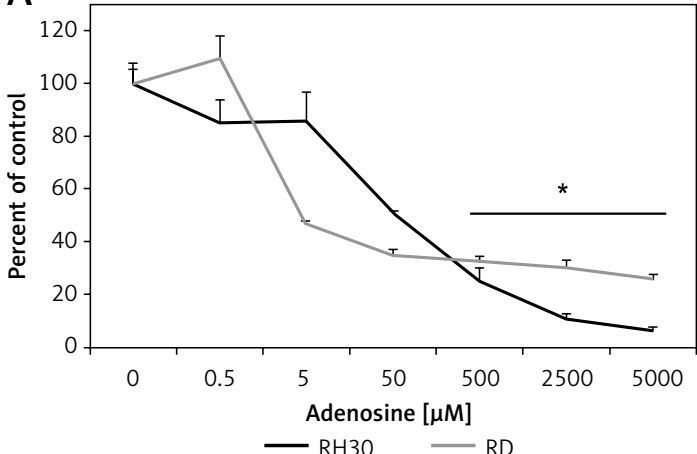

B

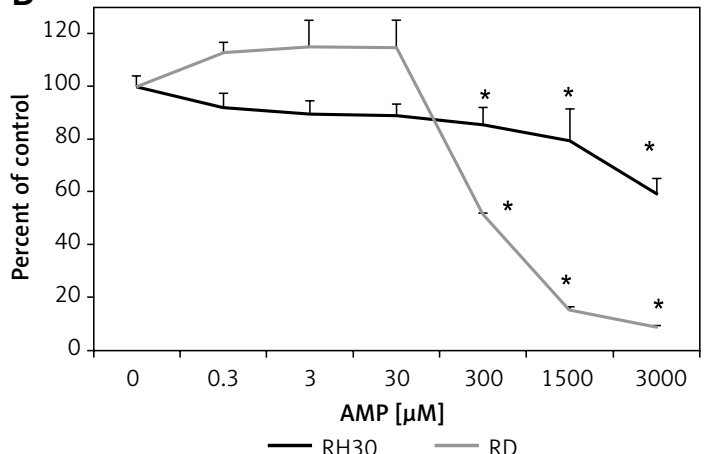

Figure 6. Adenosine and AMP-dependent cell proliferation. RH30 and RD cells were treated with increasing doses of adenosine $(0-5000 \mu \mathrm{M})$ or AMP $(0-3000 \mu \mathrm{M})$ and their proliferative capacity was measured in plastic dishes by flow cytometry. Combined data from three independent experiments are shown

${ }^{\star} P<0.05$ versus untreated controls.

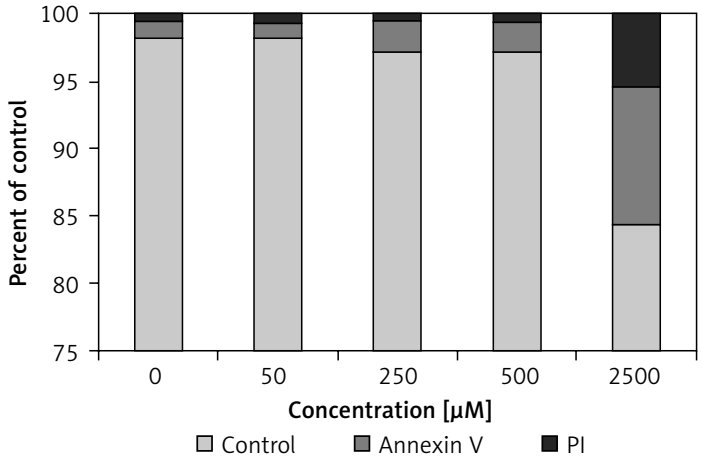

$0 \mu \mathrm{M}$ Ado

[B] ANNEXIN V/PI

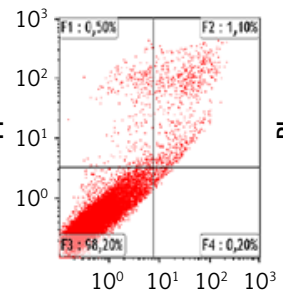

Annexin V

[UNGATED]

FS INT/SS INT

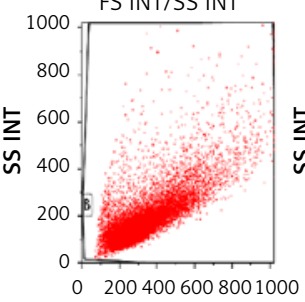

FS INT
$50 \mu \mathrm{M}$ Ado

[B] ANNEXIN V/PI

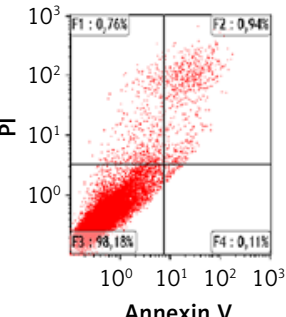

Annexin $\mathrm{V}$

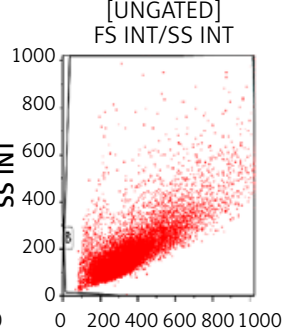

FS INT
$250 \mu \mathrm{M}$ Ado

[B] ANNEXIN V/PI

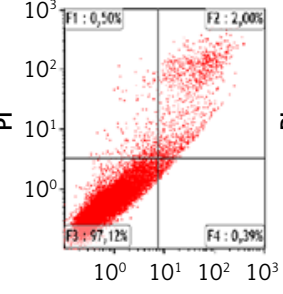

Annexin V

[UNGATED]

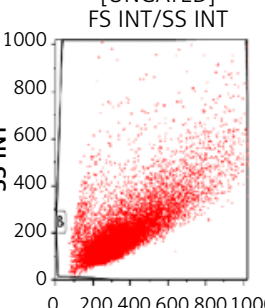

FS INT
$500 \mu \mathrm{M}$ Ado

[B] ANNEXIN V/P

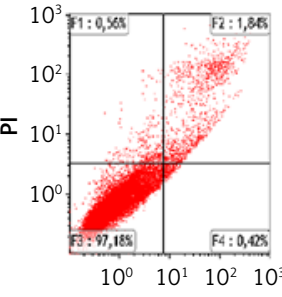

Annexin V

[UNGATED]

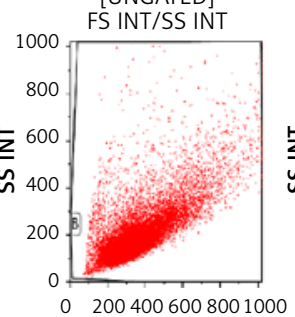

FS INT
$2500 \mu \mathrm{M}$

[B] ANNEXIN V/PI
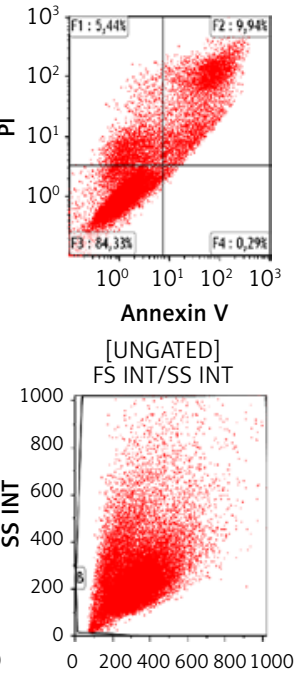

FS INT

Figure 7. Representative study of apoptosis in adenosine-treated RH30 cells. Cells were treated with $0 \mu \mathrm{M}$, $50 \mu \mathrm{M}, 250 \mu \mathrm{M}, 500 \mu \mathrm{M}$, or $2500 \mu \mathrm{M}$ of adenosine for $72 \mathrm{~h}$ and stained with propidium iodide and anti-annexin $\mathrm{V}$ antibody

adenosine transporter inhibitors it became clear that adenosine acts through the intrinsic pathway. Blockage of the Ado transporter by dipyridamole increases cell survival. What is more, application of deaminase inhibitors, which cause a further rise of adenosine concentration, strengthened the negative effect on cell proliferation (Figure 8). Such a scenario was previously documented for gastric 
A
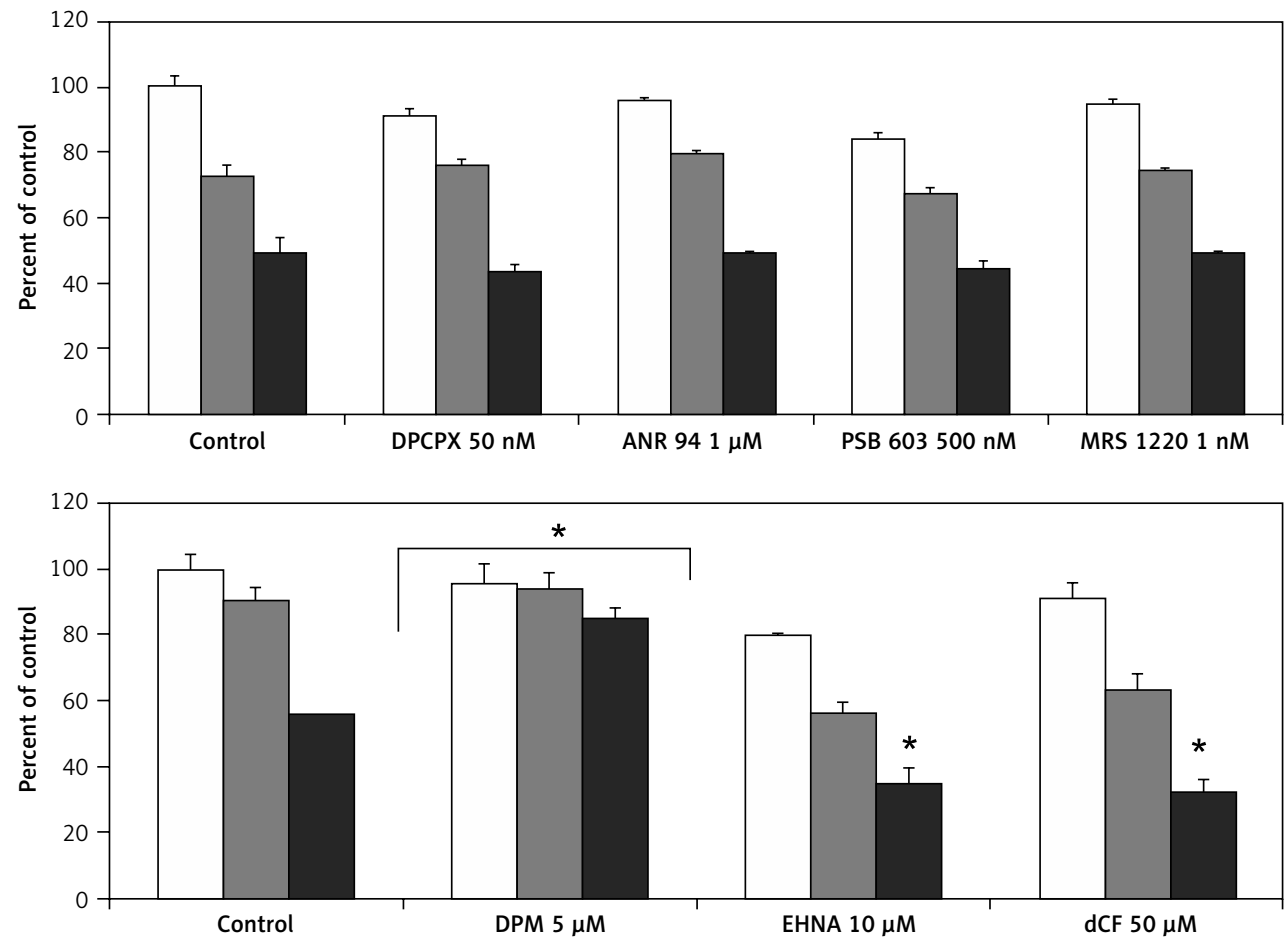

B
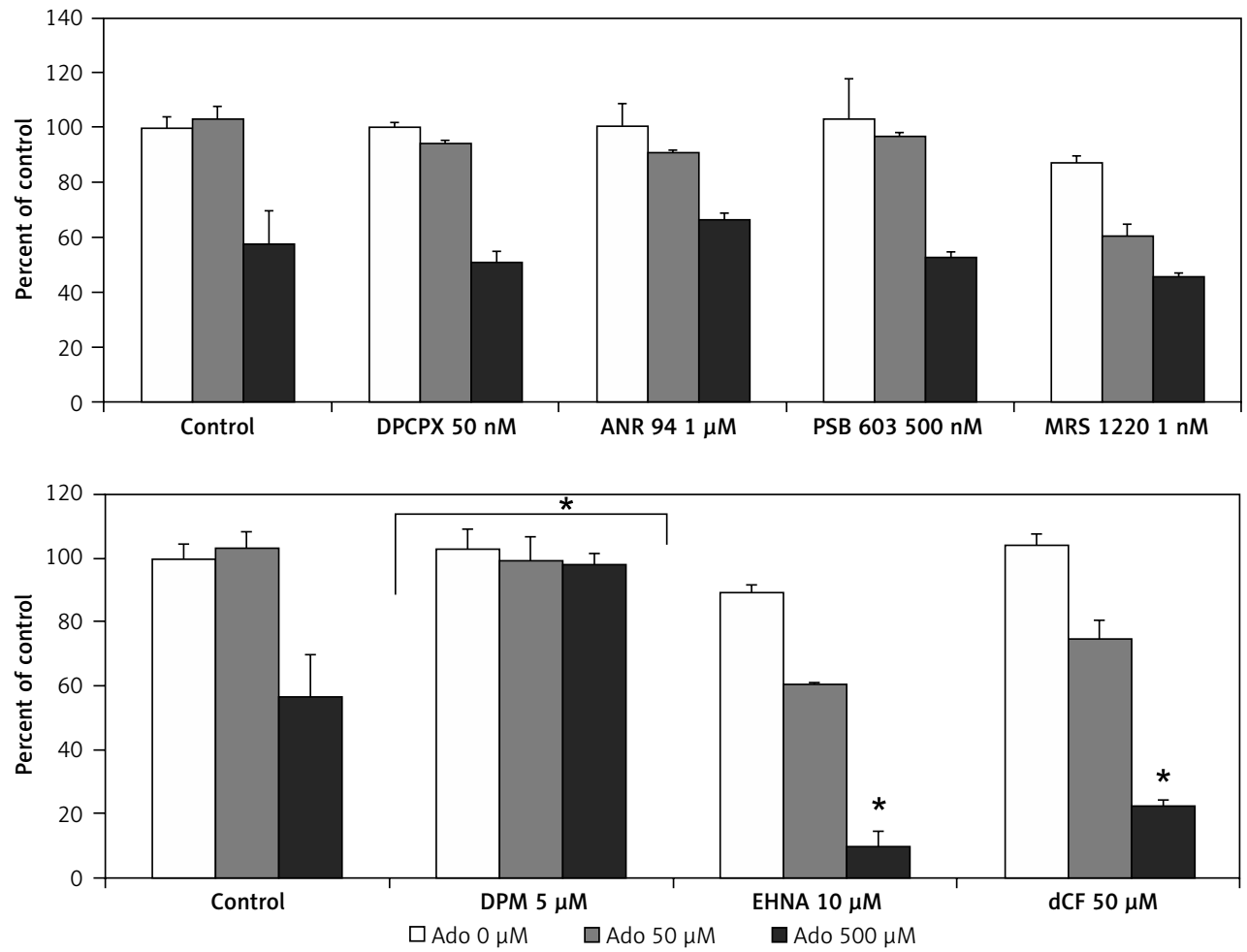

Figure 8. Effects of $A 1$ receptor antagonist (DPCPX), A2A receptor antagonist (ANR 94), A2B receptor antagonist (PSB 603), A3 receptor antagonist (MRS 1220), adenosine transporter inhibitor (dipyridamole, DPM), adenosine deaminase inhibitors (EHNA hydrochloride, EHNA and pentostatin, dCF) on adenosine $(0 \mu \mathrm{M}, 50 \mu \mathrm{M}, 500 \mu \mathrm{M})$ chemotactic (A) RH30 and (B) RD cell response. In all wells receptor antagonists and inhibitors were added 30 min before adenosine stimulation every $24 \mathrm{~h}$ for $72 \mathrm{~h}$

Data are means \pm SE of duplicate wells within a single experiment. The experiment was repeated three times. ${ }^{*} P<0.05$. 
cancer [46], human hepatoma [47] and MCF-7 breast cancer cells [48]. Typically, intracellularly transported adenosine is phosphorylated to AMP and induces apoptosis via caspase-3/-8 activation [49] or apoptosis-inducing factor (AIF)-homologous mitochondrion-associated inducer of death (AMID) translocation [47].

In conclusion, extracellular nucleotides (ATP, ADP, AMP) produced/released during states of stress such as hypoxia or cell damage are dephosphorylated by a step-wise process involving a series of ectonucleotidases. This process leads to increased concentrations of adenosine. This scenario may happen at sites of damage induced by radio- or chemotherapy [21] or wherever oxygen demand exceeds oxygen supply, as in the tumour microenvironment affected by inflammatory cytokines [50] creating the hypoxic niche of bone marrow or sites of ischaemia [51]. At first, adenosine, together with CD73 overexpression, acts as a potent chemoattractant to stimulate cancer cell metastasis. When the adenosine concentration rises further, it has a detrimental effect on cellular proliferation. This phenomenon might be encountered when adenosine deaminase activity is blocked or where the blood supply is not sufficient, as in the necrotic core of a solid tumour [52]. Notably, this high adenosine concentration may in turn stimulate angiogenesis and suppress the immune system. Thus, further studies are needed to fully understand the final role of adenosine in tumour biology and possible applications of agonists and antagonists of purinergic signalling.

\section{Acknowledgments}

This study was supported by grant FSN-133$01 / 13$ from the Pomeranian Medical University in Szczecin.

\section{Conflict of interest}

The authors eclare no conflict of interest.

\section{References}

1. Fredholm BB. Adenosine receptors as drug targets. Exp Cell Res 2010; 316: 1284-8.

2. Van Belle H, Goossens F, Wynants J. Formation and release of purine catabolites during hypoperfusion, anoxia, and ischemia. Am J Physiol 1987; 252: H886-93.

3. Blay J, White TD, Hoskin DW. The extracellular fluid of solid carcinomas contains immunosuppressive concentrations of adenosine. Cancer Res 1997; 57: 2602-5.

4. Zimmermann $\mathrm{H}$. Extracellular metabolism of ATP and other nucleotides. N-S Arch Pharmacol 2000; 362: 299309.

5. Fredholm, BB, IJzerman AP, Jacobson KA, Klotz KN, Linden J. International Union of Pharmacology. XXV. Nomenclature and classification of adenosine receptors. Pharmacol Rev 2001; 53: 527-52.

6. Dickenson JM, Blank JL, Hill SJ. Human adenosine A1 receptor and $\mathrm{P} 2 \mathrm{Y} 2$-purinoceptormediated activation of the mitogen-activated protein kinase cascade in transfected CHO cells. Br J Pharmacol 1998; 124: 1491-9.

7. Schulte G, Fredholm BB. Human adenosine A(1), A(2A), $A(2 B)$, and $A(3)$ receptors expressed in Chinese hamster ovary cells all mediate the phosphorylation of extracellular-regulated kinase 1/2. Mol Pharmacol 2000; 58: 477-82.

8. Schulte G, Fredholm BB. Signalling from adenosine receptors to mitogen-activated protein kinases. Cell Signal 2003; 15: 813-27.

9. Fishman P, Bar-Yehuda S, Synowitz M, et al. Adenosine receptors and cancer. Handb Exp Pharmacol 2009; 193: 399-441.

10. Gessi S, Merighi S, Sacchetto V, Simioni C, Borea PA. Adenosine receptors and cancer. Biochim Biophys Acta 2011; 1808: 1400-12.

11. Merighi S, Mirandola P, Varani K, et al. A glance at adenosine receptors: novel target for antitumor therapy, Pharmacol Ther 2003; 100: 31-48.

12. Stagg J, Smyth MJ. Extracellular adenosine triphosphate and adenosine in cancer. Oncogene 2010; 29: 5346-58.

13. Barr FG, Galili N, Holick J, Biegel JA, Rovera G, Emanuel BS. Rearrangement of the PAX3 paired box gene in the paediatric solid tumour alveolar rhabdomyosarcoma. Nat Genet 1993; 3: 113-7.

14. Collins MH, Zhao H, Womer RB, Barr FG. Proliferative and apoptotic differences between alveolar rhabdomyosarcoma subtypes: a comparative study of tumors containing PAX3-FKHR or PAX7-FKHR gene fusions. Med Pediatr Oncol 2001; 37: 83-9.

15. Hazelton BJ, Houghton JA, Parham DM, et al. Characterization of cell lines derived from xenografts of childhood rhabdomyosarcoma. Cancer Res 1987; 47: 4501-7.

16. Lama J, Merks JHM, Pieters BR, et al. Orbital rhabdomyosarcomas: a review. Saudi J Ophthalmol 2013; 27: 167-75.

17. Breneman J, Meza J, Donaldson SS, et al. Local control with reduced-dose radiotherapy for low-risk rhabdomyosarcoma: a report from the children's oncology group D9602 study. Int J Radiat Oncol Biol Phys 2012; 83: 720-6.

18. Arndt C, Tefft M, Gehan E. A feasibility, toxicity, and early response study of etoposide, ifosfamide, and vincristine for the treatment of children with rhabdomyosarcoma: a report from the intergroup rhabdomyosarcoma study (IRS) IV pilot study. J Pediatr Hematol Oncol 1997; 19: 124-9.

19. Schneider G, Glaser T, Lameu C, et al. Extracellular nucleotides as novel, underappreciated pro-metastatic factors that stimulate purinergic signaling in human lung cancer cells. Mol Cancer 2015; 14: 201.

20. Di Virgilio F, Adinolfi E. Extracellular purines, purinergic receptors and tumor growth. Oncogene 2017; 36: 293 303.

21. Golden EB, Frances D, Pellicciotta I, Demaria S, Helen Barcellos-Hoff M, Formenti SC. Radiation fosters dose-dependent and chemotherapy-induced immunogenic cell death. Oncoimmunology 2014; 3: e28518.

22. Grymula K, Tarnowski M, Wysoczynski M, et al. Overlapping and distinct role of CXCR7-SDF-1/ITAC and CXCR4-SDF-1 axes in regulating metastatic behavior of human rhabdomyosarcomas. Int J Cancer 2010; 27: 2554-68.

23. Fredholm BB, Irenius E, Kull B, Schulte G. Comparison of the potency of adenosine as an agonist at human adenosine receptors expressed in Chinese hamster ovary cells. Biochem Pharmacol 2001; 61: 443-8. 
24. Rittiner JE, Korboukh I, Hull-Ryde EA, Janzen WP, Frye SV, Zylka MJ. AMP is an adenosine A1 receptor agonist. J Biol Chem 2012; 287: 5301-9.

25. Tsuchiya A, Nishizaki T. Anticancer effect of adenosine on gastric cancer via diverse signaling pathways. World J Gastroenterol 2015; 21: 10931-5.

26. Fredholm BB. Purines and neutrophil leukocytes. Gen Pharmacol 1997; 28: 345-50.

27. Robson SC, Sevigny J, Zimmermann H. The E-NTPDase family of ectonucleotidases: structure function relationships and pathophysiological significance. Purinergic Signal 2006; 2: 409-30.

28. Zimmermann H, Zebisch M, Strater N. Cellular function and molecular structure of ectonucleotidases. Purinergic Signal 2012; 8: 437-502.

29. Bonan CD. Ectonucleotidases and nucleotide/nucleoside transporters as pharmacological targets for neurological disorders. CNS Neurol Disord Drug Targets 2012; 11 : 739-50.

30. Lynge J, Hellsten Y. Distribution of adenosine A1, A2A and $\mathrm{A} 2 \mathrm{~B}$ receptors in human skeletal muscle. Acta Physiol Scand 2000; 169: 283-90.

31. Greer F, Graham TE, Nagy LE. Characterization of adenosine receptors in rat skeletal muscle. Can J Appl Physio 1997; 22: 23.

32. Mirza A, Basso A, Black S, et al. RNA interference targeting of A1 receptor overexpressing breast carcinoma cells leads to diminished rates of cell proliferation and induction of apoptosis. Cancer Biol Ther 2005; 4: 1355-60.

33. Merighi S, Varani K, Gessi S, et al. Pharmacological and biochemical characterization of adenosine receptors in the human malignant melanoma $\mathrm{A} 375$ cell line. $\mathrm{Br}$ J Pharmacol 2001; 134: 1215-26.

34. Khoo HE, Ho CL, Chhatwal VJ, Chan ST, Ngoi SS, Moochhala SM. Differential expression of adenosine A1 receptors in colorectal cancer and related mucosa. Cancer Lett 1996; 106: 17-21.

35. Schulte G, Fredholm BB. Human adenosine A1, A2A, $A 2 B$, and $A 3$ receptors expressed in Chinese hamster ovary cells all mediate the phosphorylation of extracellular-regulated kinase 1/2. Mol Pharmacol 2000; 58 477-82.

36. Tomura $\mathrm{H}$, Itoh $\mathrm{H}$, Sho $\mathrm{K}$, et al. Betagamma subunits of pertussis toxin-sensitive $\mathrm{G}$ proteins mediate $\mathrm{A} 1$ adenosine receptor agonist-induced activation of phospholipase $C$ in collaboration with thyrotropin. A novel stimulatory mechanisms through the cross-talk of two types of receptors. J Biol Chem 1997; 272: 23130-7.

37. Rolland-Turner M, Goretti E, Bousquenaud $M$, et al. Adenosine stimulates the migration of human endothelial progenitor cells. Role of CXCR4 and microRNA-150. Plos One 2013; 8: e54135.

38. Othman T, Yan H, Rivkees SA. Oligodendrocytes express functional A1 adenosine receptors that stimulate cellu lar migration. Glia 2003; 44: 166-72.

39. Cronstein BN, Daguma L, Nichols D, Hutchison AJ, Williams $M$. The adenosine/neutrophil paradox resolved: human neutrophils possess both $\mathrm{A} 1$ and $\mathrm{A} 2$ receptors that promote chemotaxis and inhibit $\mathrm{O} 2$ generation, respectively. J Clin Invest 1990; 85: 1150-7.

40. Woodhouse EC, Amanatullah DF, Schetz JA, Liotta LA, Stracke ML, Clair T. Adenosine receptor mediates motility in human melanoma cells. Biochem Biophys Res Commun 1998; 246: 888-94.

41. Chen $Y$, Corriden $R$, Inoue $Y$, et al. ATP release guides neutrophil chemotaxis via $\mathrm{P} 2 \mathrm{Y} 2$ and $\mathrm{A} 3$ receptors. Science 2006; 314: 1792-5.
42. Mujoomdar M, Hoskin D, Blay J. Adenosine stimulation of the proliferation of colorectal carcinoma cell lines. Roles of cell density and adenosine metabolism. Biochem Pharmacol 2003; 66: 1737-47.

43. Mujoomdar M, Bennett A, Hoskin D, Blay J. Adenosine stimulation of proliferation of breast carcinoma cell lines: evaluation of the $[3 \mathrm{H}]$ thymidine assay system and modulatory effects of the cellular microenvironment in vitro. J Cell Physiol 2004; 201: 429-38.

44. Panjehpour M, Karami-Tehrani F. Adenosine modulates cell growth in the human breast cancer cells via adenosine receptors. Oncol Res 2007; 16: 575-85.

45. Madi L, Ochaion A, Rath-Wolfson L, et al. The A3 adenosine receptor is highly expressed in tumor versus normal cells: potential target for tumor growth inhibition. Clin Cancer Res 2004; 10: 4472-9.

46. Saitoh M, Nagai K, Nakagawa K, Yamamura T, Yamamoto $S$, Nishizaki T. Adenosine induces apoptosis in the human gastric cancer cells via an intrinsic pathway relevant to activation of AMP-activated protein kinase. Biochem Pharmacol 2004; 67: 2005-11.

47. Yang D, Yaguchi T, Nagata T, et al. AMID mediates adenosine-induced caspase-independent $\mathrm{HuH}-7$ cell apoptosis. Cell Physiol Biochem 2011; 27: 37-44.

48. Tsuchiya A, Kanno T, Saito M, et al. Intracellularly transported adenosine induces apoptosis in [corrected] MCF-7 human breast cancer cells by accumulating AMID in the nucleus. Cancer Lett 2012; 321: 65-72.

49. Yang D, Yaguchi T, Yamamoto H, Nishizaki T. Intracellularly transported adenosine induces apoptosis in $\mathrm{HuH}-7$ human hepatoma cells by downregulating c-FLIP expression causing caspase-3/-8 activation. Biochem Pharmacol 2007; 73: 1665-75.

50. Mielczarek-Palacz A, Sikora J, Kondera-Anasz Z, Mickiewicz P, Mickiewicz A. Effect of Th1/Th2 cytokine administration on proinflammatory SKOV-3 cell activation. Arch Med Sci 2016; 12: 1337-47.

51. Adair TH. Growth regulation of the vascular system: an emerging role for adenosine. Am J Physiol Regul Integr Comp Physiol 2005; 289: R283-96.

52. Carrasco E, Garrido JM, Álvarez PJ, et al. Meroxest improves the prognosis of immunocompetent $\mathrm{C} 57 \mathrm{BL} / 6$ mice with allografts of E0771 mouse breast tumor cells. Arch Med Sci 2016; 12: 919-27. 